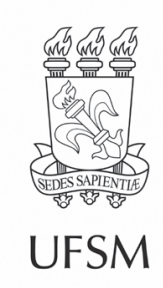

\title{
Artigos
}

\section{Floristic composition, diversity and edaphic effects in two rocky savanna communities in the Amazon and Cerrado, Brazil}

\author{
Composição florística, diversidade e efeitos edáficos em duas \\ comunidades de savanas rochosas na Amazônia e Cerrado, Brasil
}

\author{
Marcos José Gomes Pessoa' ${ }^{\oplus}$, Leonardo Maracahipes-Santos" ${ }^{\circledR}$, \\ Ana Clara Abadia"' $\odot$, Bianca de Oliveira"' $\odot$, \\ Ivone Vieira da Silvaiv $\bullet$, Eddie Lenza"I $\odot$
}

\begin{abstract}
'Universidade do Estado do Rio de Janeiro, Rio de Janeiro, RJ, Brazil "Instituto de Pesquisa Ambiental da Amazônia, Canarana, MT, Brazil '"Universidade do Estado de Mato Grosso, Nova Xavantina, MT, Brazil "Vniversidade do Estado de Mato Grosso, Alta Floresta, MT, Brazil
\end{abstract}

\begin{abstract}
Despite the uniqueness and reach of the flora from natural savannas in the Brazilian Amazon, and the existence of studies on its origin and diversity, there are no local studies associating floristic patterns with soil properties in savanna enclaves in the Amazon region of the state of Mato Grosso. Floristic composition and diversity were compared between a woody community from a rocky savanna inselberg in a transition region (RTS) between the two largest South American biomes (Cerrado-Amazon), and an enclave of rocky savanna in the Amazon (RAS), and the effects of soil properties were investigated. Floristic comparisons were also made between the two studied communities and two other rocky savanna communities near the Cerrado-Amazon transition. The flora and physical and chemical soil properties in twenty-five $20 \times 20$ m subplots ( 1 ha) in each community were sampled and georeferenced. An evident floristic distinction was found between the two studied communities, with low similarity values and a high number of indicator species. The observed and estimated richness and Rényi diversity profiles indicated lower species diversity in RAS than in RTS. Soils were found to be litholic, poorly drained, dystrophic, alic, extremely acidic, sandy and nutrient poor. Species composition and abundance was associated with soil properties in both communities. The clear difference in species composition and diversity between RTS and RAS seem to be shaped by soil properties, geographic isolation and floristic influence from the Cerrado and the Amazon. These results broaden the knowledge regarding the composition and diversity of woody plants of savannas in Amazonian enclaves and Cerrado inselbergs, and provide an important set of floristic and edaphic descriptors for the phytogeography of rocky savannas.
\end{abstract}

Keywords: Amazonian savanna; Inselbergs; Phytogeography; Cerrado-Amazonian Forest transition 


\section{RESUMO}

Apesar da singularidade e extensão da flora de savanas naturais na Amazônia brasileira, e da existência de trabalhos sobre sua origem e diversidade, não há estudos locais que associam padrões florísticos com propriedades do solo em enclaves de cerrado na região amazônica no estado de Mato Grosso. Comparamos a composição florística e a diversidade entre uma comunidade lenhosa de um inselberg de savana rochosa em uma região de transição (STR) entre os dois maiores biomas sul-americanos (Cerrado-Amazônia) e um enclave de savana rochosa na Amazônia (SAR) e investigamos os efeitos das propriedades do solo. Além disso, comparamos as duas comunidades estudadas com outras duas comunidades de savanas rochosas próximos da transição Cerrado-Amazônia. A flora e as propriedades físicas e químicas do solo de vinte e cinco subparcelas de $20 \times 20$ m (1 ha), em cada comunidade foram amostradas e georreferenciadas. Uma evidente distinção florística foi encontrada entre as duas comunidades estudadas, com baixos valores de similaridade e um número elevado de espécies indicadoras. A riqueza observada e estimada e os perfis de diversidade de Rényi indicaram menor diversidade de espécies na SAR do que na STR. Os solos são litólicos, pouco drenados, distróficos, álicos, extremamente ácidos, arenosos e pobres em nutrientes em ambas as comunidades. A composição e a abundância de espécies foram associadas às propriedades do solo. A clara diferença na composição e diversidade entre STR e SAR parecem ser moldadas pelas propriedades do solo, isolamento geográfico e influências florísticas do Cerrado e Amazônia. Esses resultados ampliam o conhecimento sobre a composição e diversidade de plantas lenhosas de savanas em enclaves da Amazônia e inselbergs do Cerrado e fornecem um importante conjunto de descritores florísticos e edáficos para a fitogeografia de savanas rochosas.

Palavras-chave: Savanas amazônicas; Inselbergs; Fitogeografia; Transição Cerrado-Floresta Amazônica

\section{INTRODUCTION}

A major challenge in ecological studies is to understand the roles of the environment and geographic isolation on the assemblage of isolated plant communities in the landscape. Soil properties, geographical distance and floristic influence from neighboring communities play important roles in determining plant species distributions and diversity in Neotropical savannas (ABADIA et al., 2018; ROCHA; NETO, 2019). Neotropical inselbergs are patches of isolated habitats with rocky outcrops and different ecological conditions and vegetation from the surrounding landscape (POREMBSKI; SILVEIRA; FIEDLER, 2016). In turn, enclaves are patches of vegetation representative of ecosystems belonging to phytogeographic provinces totally distinct from those within which they are embedded and are characterized by specific and unique floral elements (RATTER; BRIDGEWATER; RIBEIRO, 2003; ROCHA; NETO, 2019). 
In the Cerrado biome, inselbergs of rocky savanna vegetation, locally called Cerrado Rupestre, are generally surrounded by fields and savannas on deep soil (PINTO; LENZA; PINTO, 2009). In the Amazon Basin, enclaves of savanna-type vegetation, known as Amazonian savannas, are characterized by their distinct species composition, structure, and ecology in comparison with savanna formations of the Cerrado of the Central Brazilian Plateau and other regions of South America, due to their affinities with adjacent tropical forest systems (RATTER; BRIDGEWATER; RIBEIRO, 2003; ROCHA; NETO, 2019). Thus, comparisons between Cerrado inselbergs and Amazonian enclaves provide a good opportunity to evaluate the effect of isolation, and the edaphic and floristic influence on species composition and diversity in these savannas.

Isolated enclaves of Amazonian savanna are found in the Brazilian states, where they grow on distinct substrates, which are generally acidic and dystrophic (RATTER; BRIDGEWATER; RIBEIRO, 2003). Studies on plant communities from Amazonian savannaslocated on deep soils indicate that species richness and diversity are lower than for communities typically found in savannas of the Cerrado (RATTER; BRIDGEWATER; RIBEIRO, 2003; ROCHA; NETO, 2019). However, no data are available for Amazonian savanna enclaves on litholic soils. In contrast, woody or shrubby-arboreal savanna communities associated with rocky outcrops in the Cerrado biome have been amply studied in recent years (ABADIA et al., 2018). These authors showed the richness in savannas on rocky outcrops is similar to that found in adjacent savannas on deep soils. In general, these results suggest that the assemblage of woody communities is different between the rocky amazonian savanna enclaves and the Cerrado rocky savanna inselbergs.

Thus, this study aimed to increase knowledge regarding the processes that support biological diversity by comparing species composition and diversity, and investigating the influence of soil properties on floristic patterns, of two savanna woody communities: a savanna inselberg in a transition region between the Cerrado and Amazon, and an enclave of rocky savanna in the Amazon. The two studied floristic communities were also compared with two other communities of rocky cerrado near the Cerrado-Amazon transition. 


\section{MATERIAL AND METHODS}

\subsection{Study area}

Three biomes occur in the state of Mato Grosso: Amazon, Cerrado and Pantanal (Figure 1). Here, we studied and compared the flora and the soil of two isolated woody communities (including monocots and lianas) found on rocky outcrops and separated by $520 \mathrm{~km}$ one each other (Figure 1). The first community (Figure 1a) is located near the banks of the Teles Pires River in a Permanent Preservation Area of the Colíder Hydroelectric Plant reservoir, in the municipality of Nova Canaã do Norte, Mato Grosso. This community grows on arenitic origin rocks of and is surrounded by dense and open Submontane Ombrophilous Forests, and on the other side by swamp bushes. Thus, this community is referred here as rocky amazonian savanna (RAS), in order to distinguish it from the other savannas that grow on deep soils scattered and isolated in the Amazon. The local climate is warm and humid equatorial (Am), according to the classification of Köppen, with temperatures ranging from $20^{\circ} \mathrm{C}$ to $29^{\circ} \mathrm{C}$, and the mean annual temperature exceeding $27^{\circ} \mathrm{C}$ (ALVARES et al., 2013). Total annual rainfall can reach 3,100 $\mathrm{mm}$ with two well-defined seasons: a rainy season from October to April, and a dry season from May to September (ALVARES et al., 2013). The region is composed of a variety of different geological units, with the topography ranging from flat or gently sloping plains to very steep mountainous terrain (BERNASCONI et al., 2009). A variety of soils can also be found in the region, although three types are predominant: red-yellow clays, litholicneosols, and red-yellow latosols (BERNASCONI et al., 2009). The second community (Figure $1 \mathrm{~b}$ ), referred here as rocky transition savanna (RTS), is located in a legal reserve, in a private property in the municipality of Ribeirão Cascalheira at the northwest border of the transition between the Cerrado and the Amazon. This community is surrounded by savanna and transitional forest both growing on deep soils, dystrophic or mesotrophic (RATTER; BRIDGEWATER; RIBEIRO, 2003). The climate of the region is rainy tropical savanna (Aw), according to the 
classification of Köppen, with rainy summers and dry winters, temperatures ranging from $17^{\circ} \mathrm{C}$ to $26^{\circ} \mathrm{C}$, a mean annual temperature exceeding $24^{\circ} \mathrm{C}$, and annual rainfall ranging from 1,900 to $2,500 \mathrm{~mm}$, characterized by a well-defined rainy season, from October and April, and a cooler, dry season between May and September (ALVARES et al., 2013). Both communities are well preserved, once they are located in preservation areas, and during this study, we did not notice recent signal of fire, cattle presence and logging.

Figure 1 - Location of sampling sites and arrangement of plots and subplots in a rocky amazonian savanna in Nova Canaã do Norte - RAS (a) and in a rocky transition savanna in Ribeirão Cascalheira - RTS (b) in the state of Mato Grosso, Brazil

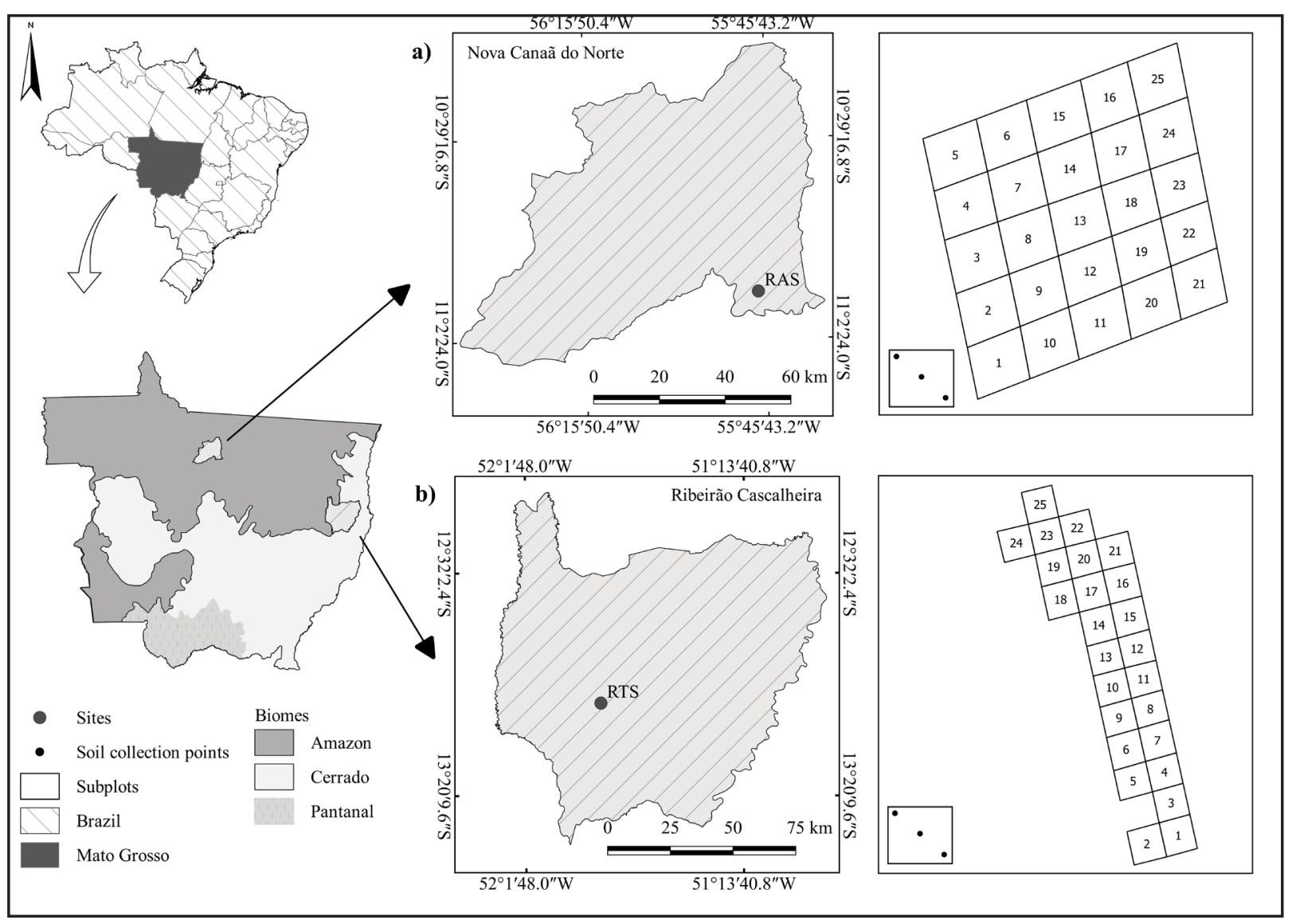

Source: Authors (2021)

In where: Grids on the right show the sampling design and the soil sampling sites $(\bullet)$. 


\subsection{Data collection}

A 1-hectare plot was delimited in each community, although the shape of the plots differed (Figure 1). A $100 \mathrm{~m} \times 100 \mathrm{~m}$ plot was established in RAS, which was divided into 25 subplots of $20 \mathrm{~m} \times 20 \mathrm{~m}$. Since the rocky outcrop of RTS is very narrow, making it impossible to demarcate a $100 \mathrm{~m} \times 100 \mathrm{~m}$ square plot as in RAS, an irregularshaped plot divided into 25 subplots of $20 \mathrm{~m} \times 20 \mathrm{~m}$, was established. All live woody plants (including shrubs, trees, and lianas) with a basal diameter of at least $5 \mathrm{~cm}$ at $30 \mathrm{~cm}$ above the ground $\left(\mathrm{Bd}_{30} \mathrm{~cm} ;\right.$ MORO; MARTINS, 2011) were identified within each subplot.

Species were identified in the field when possible, while specimens were collected for further analysis in the laboratory based on specific literature, consultation with taxonomic experts, and comparisons with specimens of the Southern Amazonia Herbarium (HERBAM), in the municipality of Alta Floresta (UNEMAT) and the Herbarium NX, in the municipality of Nova Xavantina, both in the state of Mato Grosso, Brazil. Taxonomic classification of the specimens was based on APG IV (ANGIOSPERM PHYLOGENY GROUP, 2016), while species names were based on data available from the Flora do Brasil website (JARDIM BOTÂNICO DO RIO DE JANEIRO, 2019).

We collected three soil samples from each subplot at a depth of $0-20 \mathrm{~cm}$. One sample was collected at the center of each subplot and the other two were collected close to the opposite vertices. These samples were homogenized to form a single composite sample representing each subplot for analysis (Figure 1). The physicalchemical soils properties analyzed were potassium (K), sulfur (S), copper (Cu), saturation by aluminum (Sat. Al), sand, phosphorus (P), calcium (Ca), boron (B), iron (Fe), zinc (Zn), sodium ( $\mathrm{Na}$ ), base saturation (Sat. Base), silt, magnesium (Mg), aluminum (Al), potential acidity $(\mathrm{H}+\mathrm{Al})$, organic matter, manganese $(\mathrm{Mn})$, cation exchange capacity $(\mathrm{CEC}), \mathrm{pH}$ and clay, according to Santos et al. (2018). 
Pessoa, M. J. G.; Maracahipes-Santos, L.; Abadia, A. C.; Oliveira, B.; Silva, I. V.; Lenza, E. | 1389

\subsection{Data analysis}

Species richness was compared between communities using rarefaction with 1,000 randomizations and sampling standardized by the number of individuals (GOTELLI; COLWELL, 2001). This method is used to compare communities sampled with different sampling efforts (GOTELLI; COLWELL, 2001; MAGURRAN, 2011). We used diversity profiles based on the Rényi exponential series to compare species diversity of the two communities (TÓTHMÉRÉSZ, 1995). We performed these analyses in the PAST software (Paleontological S Tatistics), version 2.15.

Principal Coordinates Analysis (PCOA) using the Bray-Curtis dissimilarity index was used to evaluate whether the two communities (RTS and RAS) formed distinct groups based on species composition and abundance (LEGENDRE; LEGENDRE, 2012). The significance of the groups formed by the PCOA was tested using ANOSIM with Bonferroni correction (CLARKE; WARWICK, 1994). These analyses were run in the vegan package (OKSANEN et al., 2018) of the R statistical programming environment, version 3.4.4 (R CORE TEAM, 2018). Density and the Importance Value Index (IV) were calculated for each species of the two communities (MUELLER-DOMBOIS; ELLENBERG, 1974), which were then compared using the ten species with the highest IV scores. This analysis was run using FITOPAC 2.1.2 software (SHEPHERD, 2009). An Indicator Species Analysis (ISA) was performed with a Monte Carlo test to evaluate the significance of

each species as an indicator of each community (DUFRÊNE; LEGENDRE, 1997). This analysis was performed with PC-ORD software version 6.07 (MCCUNE; MEFFORD, 2011).

The species composition of the two studied communities was compared with that of two others rocky Cerrado communities located near the southern border of the Amazon biome using Sørensen's qualitative index (CS) (BROWER; ZAR, 1984) and 
Morisita's quantitative index $\left(\mathrm{I}_{\mathrm{M}}\right)$ (MAGURRAN, 2011). Both indices were calculated using the PAST (Paleontological S Tatistics) software, version 2.15. One of these communities was located in the municipality of Nova Xavantina, state of Mato Grosso (see GOMES et al., 2011) while the other was in the municipality of Piranhas, state of Goiás (see ABREU et al., 2012). These sites are located $200 \mathrm{~km}$ and $395 \mathrm{~km}$ south, respectively, from RTS. Since RTS is located at the southern extreme of the transition between the Amazon and the Cerrado (see Figure 1 and geographical coordinates in Table 1), we considered the two additional sites to represent a gradient of distance from the Amazon biome.

Table 1 - Geographic characteristics for the compared savanna communities on rocky outcrops in the states of Mato Grosso and Goiás, Brazil

\begin{tabular}{lcccc}
\hline \multicolumn{1}{c}{ Codes } & Locality & Latitude $(\mathbf{S})$ & Longitude (W) & Altitude (m) \\
\hline RTS & RibeirãoCascalheira - MT * & $13^{\circ} 00^{\prime} 09.8^{\prime \prime}$ & $51^{\circ} 45^{\prime} 12.5^{\prime \prime}$ & 403 \\
RAS & Nova Canaã do Norte - MT * & $10^{\circ} 53^{\prime} 98.7^{\prime \prime}$ & $55^{\circ} 46^{\prime} 68.7^{\prime \prime}$ & 437 \\
RNS & Nova Xavantina - MT \# & $14^{\circ} 41^{\prime} 00^{\prime \prime}$ & $52^{\circ} 20^{\prime} 00^{\prime \prime}$ & 346 \\
RPS & Piranhas - GO & $16^{\circ} 26^{\prime} 55^{\prime \prime}$ & $51^{\circ} 53^{\prime} 58^{\prime \prime}$ & 810 \\
\hline
\end{tabular}

Source: Authors (2021)

In where: RTS = rocky transition savanna in Ribeirão Cascalheira; RAS = rocky amazonian savanna in Nova Canaã do Norte; RNS = rocky savanna in Nova Xavantina; RPS = rocky savanna in Piranhas; *Present study; \#Gomes et al. (2011); ^Abreu et al. (2012).

Edaphic variables were pre-selected using the Variance Inflation Factor (VIF) < 10. Following this analysis, 13 out of 21 edaphic variables were selected for further analysis (see Table 4). Redundancy Analysis - RDA (LEGENDRE; BORCARD; ROBERST, 2012) was used to test the association between edaphic variables and floristic composition of the communities. Finally, the significance of the communities was tested using a Monte Carlo permutation test with 999 permutations. All these analyses were performed in R environment, using the usdm package for VIF (NAIMI et al., 2014), and the vegan package for RDA (OKSANEN et al., 2018). 
Pessoa, M. J. G.; Maracahipes-Santos, L.; Abadia, A. C.; Oliveira, B.; Silva, I. V.; Lenza, E. | 1391

\section{RESULTS}

A total of 1,560 woody plants of 86 species were recorded (796 at RTS and 764 at RAS), of which only 13 species (15.1\%) were common to both communities, 51 only in RTS (59.3\%) and 22 only in RAS (25.6\%). The number of species recorded in RTS ( $n=$ 64) was considerably greater than the number recorded in RAS $(n=35)$ (Table 2$)$.

Table 2 - Floristic list and phytosociological parameters of woody species sampled in two savanna communities on rocky outcrops in the state of Mato Grosso, Brazil

\begin{tabular}{|c|c|c|c|c|c|c|}
\hline \multirow{2}{*}{ Codes } & \multirow{2}{*}{ Species } & \multirow{2}{*}{ Families } & \multicolumn{2}{|c|}{ AD } & \multicolumn{2}{|c|}{ IV } \\
\hline & & & RTS & RAS & RTS & RAS \\
\hline Vatmac & Vatairea macrocarpa (Benth.) Ducke $\mathbf{~} \#$ & Fabaceae & 63 & 2 & 25.56 & 1.36 \\
\hline Quapar & Qualea parviflora Mart. $\square$ \# & Vochysiaceae & 89 & 6 & 25.44 & 3.86 \\
\hline Xylaro & Xylopia aromatica (Lam.) Mart. $\mathbf{\|} \#$ & Annonaceae & 70 & 1 & 21.64 & 0.59 \\
\hline Myrsp. & Myrcia sp. $\mathbf{\square} \#$ & Myrtaceae & 63 & 6 & 19.48 & 3.39 \\
\hline Davell & Davilla elliptica A. St. -Hil. ш \# & Dilleniaceae & 66 & - & 19.20 & - \\
\hline Anaocc & Anacardium occidentale L. $\mathbf{\Delta} \bullet \#$ & Anacardiaceae & 34 & 19 & 16.57 & 11.34 \\
\hline Ptepub & Pterodon pubescens (Benth.) Benth. . \# & Fabaceae & 18 & - & 12.20 & - \\
\hline Salcon & Salvertia convallariodora A. St. -Hil. = \# & Vochysiaceae & 18 & - & 9.69 & - \\
\hline Ferell & Ferdinandusa elliptica (Pohl) Pohl a \# & Rubiaceae & 23 & - & 9.87 & - \\
\hline Byrpac & Byrsonima pachyphylla A. Juss. — \# & Malpighiaceae & 20 & - & 8.52 & - \\
\hline Emmnit & Emmotum nitens (Benth.) Miers & Icacinaceae & 16 & 11 & 7.71 & 5.17 \\
\hline Curame & Curatella americana $\mathrm{L}$. \# & Dilleniaceae & 23 & - & 7.59 & - \\
\hline Byrcoc & Byrsonima coccolobifolia Kunth \# & Malpighiaceae & 19 & - & 7.42 & - \\
\hline Pouram & Pouteria ramiflora (Mart.) Radlk. \# & Sapotaceae & 14 & - & 7.24 & - \\
\hline Hirgla & Hirtella glandulosa Spreng. \# & Chrysobalanaceae & 17 & - & 7.56 & - \\
\hline Ourhex & Ouratea hexasperma (A.St.-Hil.) Baill. \# & Ochnaceae & 18 & - & 6.31 & - \\
\hline Consub & Connarus suberosus Planch. \# & Connaraceae & 18 & - & 6.07 & - \\
\hline Myrmul & Myrcia multiflora (Lam.) DC. & Myrtaceae & 23 & - & 5.75 & - \\
\hline Kiecor & Kielmeyera coriacea Mart. \& Zucc. \# & Calophyllaceae & 14 & - & 5.25 & - \\
\hline Mapgui & Maprounea guianensis Aubl. $\boldsymbol{\Delta} \downarrow$ & Euphorbiaceae & 14 & 34 & 4.84 & 15.14 \\
\hline Guagra & $\begin{array}{l}\text { Guapira graciliflora (Mart. ex Schmidt) } \\
\text { Lundell \# }\end{array}$ & Nyctaginaceae & 9 & - & 3.89 & - \\
\hline Hetbyr & Heteropterys byrsonimifolia A. Juss. \# & Malpighiaceae & 11 & - & 3.82 & - \\
\hline Myrvar & Myrcia variabilis DC. \# & Myrtaceae & 11 & - & 3.61 & - \\
\hline Ferdsp & Ferdinandusa sp. \# & Rubiaceae & 9 & - & 3.42 & - \\
\hline Andcuj & Andira cujabensis Benth. & Fabaceae & 5 & 11 & 3.32 & 6.81 \\
\hline
\end{tabular}

To be continued ... 
Table 1 - Continuation

\begin{tabular}{|c|c|c|c|c|c|c|}
\hline \multirow{2}{*}{ Codes } & \multirow{2}{*}{ Species } & \multirow{2}{*}{ Families } & \multicolumn{2}{|c|}{ AD } & \multicolumn{2}{|c|}{ IV } \\
\hline & & & RTS & RAS & RTS & RAS \\
\hline Roumon & Roupala montana Aubl. & Proteaceae & 11 & - & 3.29 & - \\
\hline Aspmac & Aspidosperma macrocarpon Mart. & Apocynaceae & 6 & 2 & 3.25 & 1.52 \\
\hline Chakap & $\begin{array}{c}\text { Chaunochiton kappleri (Sagot ex Engl.) } \\
\text { Ducke * \# }\end{array}$ & Olacaceae & 8 & - & 3.23 & - \\
\hline Fricin & $\begin{array}{l}\text { Fridericia cinnamomea (DC.) L. G. } \\
\text { Lohmann }\end{array}$ & Bignoniaceae & 6 & 1 & 2.40 & 0.59 \\
\hline Vocruf & Vochysia rufa Mart. & Vochysiaceae & 5 & 2 & 2.20 & 1.57 \\
\hline Hymsti & Hymenaea stigonocarpa Mart. ex Hayne & Fabaceae & 6 & - & 2.04 & - \\
\hline Strpse & Strychnos pseudoquina A. St. -Hil. & Loganiaceae & 2 & - & 1.96 & - \\
\hline Erigra & Eriotheca gracilipes (K. Schum.) A. Robyns & Malvaceae & 4 & - & 1.95 & - \\
\hline Myrsp. & Myrcia sp. & Myrtaceae & 5 & - & 1.77 & - \\
\hline Salcra & $\begin{array}{c}\text { Salacia crassifolia (Mart. ex Schult.) G. } \\
\text { Don }\end{array}$ & Celastraceae & 3 & - & 1.65 & - \\
\hline Mezcra & $\begin{array}{l}\text { Mezilaurus crassiramea (Meisn.) Taub. ex } \\
\text { Mez }\end{array}$ & Lauraceae & 3 & - & 1.64 & - \\
\hline Himart & Himatanthus articulatus (Vall) Woodson & Apocynaceae & 4 & - & 1.58 & - \\
\hline Bowvir & Bowdichia virgilioides Kunth & Fabaceae & 3 & - & 1.49 & - \\
\hline Eugpun & Eugenia punicifolia (Kunth) DC. & Myrtaceae & 3 & - & 1.42 & - \\
\hline Lepdas & Leptolobium dasycarpum Vogel. & Fabaceae & 3 & - & 1.40 & - \\
\hline Erysub & Erythroxylum suberosum A. St. -Hil. & Erythroxylaceae & 3 & - & 1.34 & - \\
\hline Buctom & $\begin{array}{c}\text { Terminalia corrugata (Ducke) Gere \& } \\
\text { Boatwr. }\end{array}$ & Combretaceae & 3 & - & 1.33 & - \\
\hline Rouind & Rourea induta Planch. & Connaraceae & 3 & - & 1.30 & - \\
\hline Tacaur & Tachigali aurea Tul. & Fabaceae & 2 & - & 1.22 & - \\
\hline Mouell & Mouriri elliptica Mart. & Melastomataceae & 3 & - & 1.12 & - \\
\hline Carbra & Caryocar brasiliense Cambess. & Caryocaraceae & 1 & - & 1.11 & - \\
\hline Tapgui & Tapirira guianensis Aubl. * & Anacardiaceae & 2 & - & 1.07 & - \\
\hline Euggem & Eugenia gemmiflora O. Berg & Myrtaceae & 3 & - & 1.02 & - \\
\hline Carcal & Cardiopetalum calophyllum Schltdl. * & Annonaceae & 2 & - & 0.95 & - \\
\hline Plaret & Plathymenia reticulate Benth. & Fabaceae & 2 & - & 0.92 & - \\
\hline Hanser & Handroanthus serratifolius (Vahl) S. Grose & Bignoniaceae & 2 & - & 0.91 & - \\
\hline Micven & $\begin{array}{c}\text { Micropholis venulosa (Mart. \& Eichler) } \\
\text { Pierre * }\end{array}$ & Sapotaceae & 1 & - & 0.65 & - \\
\hline Lafpac & Lafoensia pacari A. St. -Hil & Lythraceae & 1 & - & 0.60 & - \\
\hline Dioser & Diospyros sericea A. DC. & Ebenaceae & 1 & - & 0.51 & - \\
\hline Moupus & Mouriri pusa Gardner & Melastomataceae & 1 & 1 & 0.51 & 0.63 \\
\hline
\end{tabular}

To be continued ... 
Table 1 - Continuation

\begin{tabular}{|c|c|c|c|c|c|c|}
\hline \multirow{2}{*}{ Codes } & \multirow{2}{*}{ Species } & \multirow{2}{*}{ Families } & \multicolumn{2}{|c|}{ AD } & \multicolumn{2}{|c|}{ IV } \\
\hline & & & RTS & RAS & RTS & RAS \\
\hline Licbla & Licania blackii Prance & Chrysobalanaceae & 1 & - & 0.50 & - \\
\hline Hanspe & Hancornia speciosa Gomes & Apocynaceae & 1 & 1 & 0.48 & 0.67 \\
\hline Vissp & Vismia sp. & Hypericaceae & 1 & - & 0.47 & - \\
\hline Aspmul & Aspidosperma multiflorum A. DC & Apocynaceae & 1 & - & 0.46 & - \\
\hline Agobra & $\begin{array}{l}\text { Agonandra brasiliensis Miers ex Benth. \& } \\
\text { Hook. f. }\end{array}$ & Opiliaceae & 1 & - & 0.45 & - \\
\hline Andver & Andira vermifuga (Mart.) Benth. & Fabaceae & 1 & - & 0.44 & - \\
\hline Anncor & Annona coriacea Mart. & Annonaceae & 1 & - & 0.43 & - \\
\hline Corell & Cordiera elliptica (Cham.) Kuntze & Rubiaceae & 1 & - & 0.43 & - \\
\hline Micalb & Miconia albicans (Sw.) Triana & Melastomataceae & 1 & - & 0.43 & - \\
\hline Kierub & Kielmeyera rubriflora Cambess. $\boldsymbol{\Delta} \dagger$ & Calophyllaceae & - & 163 & - & 50.76 \\
\hline Parcac & Parkia cachimboensis H. C. Hopkins $\boldsymbol{\Delta}$ * † & Fabaceae & - & 126 & - & 45.35 \\
\hline Macrad & Macairea radula (Bonpl.) DC. $\mathbf{\Delta} \dagger$ & Melastomataceae & - & 94 & - & 26.93 \\
\hline Alcdis & Alchornea discolor Poepp. $\boldsymbol{\Delta}$ * † & Euphorbiaceae & - & 59 & - & 23.37 \\
\hline Norgui & Norantea guianensis Aubl. $\boldsymbol{\Delta} * * \dagger$ & Marcgraviaceae & - & 59 & - & 22.46 \\
\hline Simver & Simarouba versicolor A. St. -Hil. $\boldsymbol{\Delta} \dagger$ & Simaroubaceae & - & 38 & - & 13.53 \\
\hline Pagthy & $\begin{array}{c}\text { Pagamea cf. thyrsiflora Spruce ex Benth. } \\
\qquad \dagger\end{array}$ & Rubiaceae & - & 25 & - & 11.71 \\
\hline Dacmic & Dacryodes microcarpa Cuatrec. $\boldsymbol{\Delta} \dagger$ & Burseraceae & - & 22 & - & 10.93 \\
\hline Byrcra & Byrsonima crassifolia (L.) Kunth. † & Malpighiaceae & - & 11 & - & 6.47 \\
\hline Myrcit & Myrcia cf. citrifolia (Aubl.) Urb. † & Myrtaceae & - & 12 & - & 5.54 \\
\hline Chadum & $\begin{array}{c}\text { Chamaecrista dumalis (Hoehne) H.S. } \\
\text { Irwin \& Barneby. } \dagger\end{array}$ & Fabaceae & - & 12 & - & 5.13 \\
\hline Tacsub & $\begin{array}{l}\text { Tachigali subvelutina (Benth.) Oliveira- } \\
\text { Filho }\end{array}$ & Fabaceae & - & 5 & - & 4.34 \\
\hline Chrsp & Chrysophyllum sp. & Sapotaceae & - & 11 & - & 4.09 \\
\hline Ficmat & Ficus cf. mathewsii (Miq.) Miq. † & Moraceae & - & 9 & - & 4.03 \\
\hline Bredsp & Bredemeyera sp. & Polygalaceae & - & 5 & - & 2.60 \\
\hline Licape & $\begin{array}{c}\text { Leptobalanus apetalus (E. Mey.) Sothers } \\
\text { \& Prance }\end{array}$ & Chrysobalanaceae & - & 4 & - & 2.33 \\
\hline Humbal & Humiria balsamifera (Aubl.) J.St.-Hil. * & Humiriaceae & - & 2 & - & 2.02 \\
\hline Cybful & $\begin{array}{l}\text { Cybianthus cf. fulvopulverulentus (Mez) G. } \\
\text { Agostini }\end{array}$ & Primulaceae & - & 3 & - & 1.83 \\
\hline Ferchl & $\begin{array}{l}\text { Ferdinandusa cf. chlorantha (Wedd.) } \\
\text { Standl. * }\end{array}$ & Rubiaceae & - & 3 & - & 1.82 \\
\hline Vochae & Vochysia haenkeana Mart. & Vochysiaceae & - & 2 & - & 0.88 \\
\hline
\end{tabular}

To be continued ... 
Table 1 - Conclusion

\begin{tabular}{lcccccc}
\hline \multirow{2}{*}{ Codes } & \multirow{2}{*}{ Species } & \multirow{2}{*}{ Families } & \multicolumn{2}{c}{ AD } & \multicolumn{3}{c}{ IV } \\
\cline { 4 - 6 } & Manihot caerulescens Pohl & Euphorbiaceae & - & 1 & - & 0.61 \\
Mancae & Erythroxylum cf. anguifugum Mart. & Erythroxylaceae & - & 1 & - & 0.60 \\
\hline Eryang & Total & & 796 & 764 & 300 & 300 \\
\hline \multicolumn{2}{c}{} & & & &
\end{tabular}

Source: Authors (2021)

In where: RTS = rocky transition savanna in Ribeirão Cascalheira; RAS = rocky amazonian savanna in Nova Canaã do Norte; $A D$ = Absolute Density (number of individuals per ha ${ }^{-1}$ ) and IV = relative Importance Value; $\boldsymbol{\|}=$ highest IV in RTS; $\boldsymbol{\Delta}$ = highest IV in RAS; * = species typical of forest formations; $*$ * = rocky cerrado specialist species; = species common to both RTS and RAS; \# = indicator species of RTS; and $\dagger$ $=$ indicator species of RAS.

Rarefaction curves (Figure 2A) confirmed the differences between the two communities, once estimated richness was higher in RST. Also, diversity profiles indicated greater diversity for RTS, regardless of the diversity index used (Figure 2B).

Figure 2 - Species rarefaction curves (A) and species diversity profiles in the Rényi exponential series (B) for the studied savanna communities on rocky outcrops in the state of Mato Grosso, Brazil

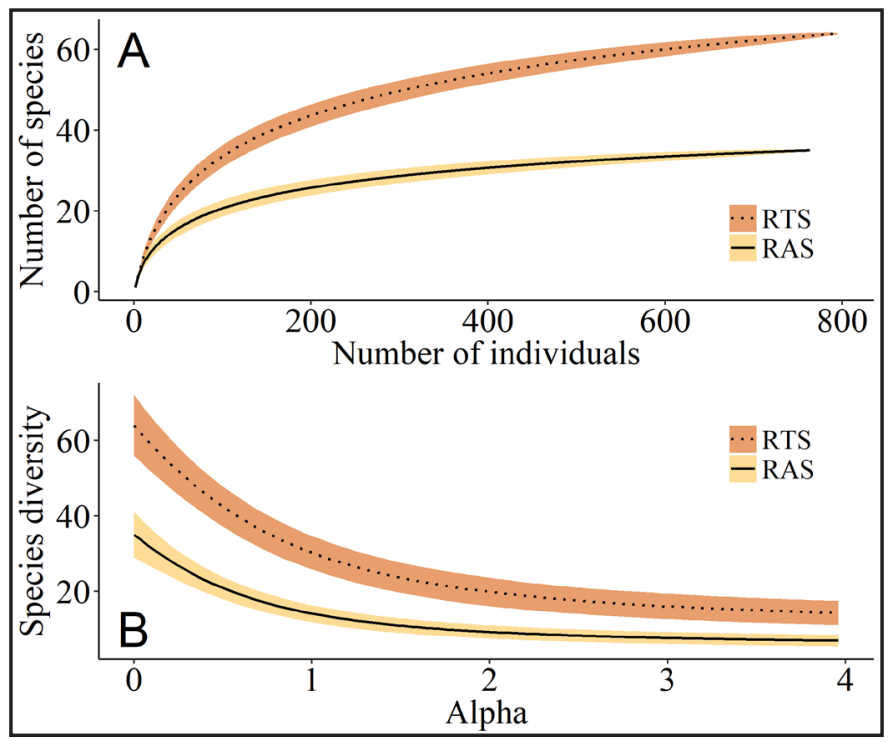

Source: Authors (2021)

In where: RTS = rocky transition savanna in Ribeirão Cascalheira; RAS = rocky amazonian savanna in Nova Canaã do Norte. 
The two communities differed in species composition, with the PCoA forming two distinct groups (Figure 3), which were confirmed by $\operatorname{ANOSIM}(R=0.97, p=0.001)$. The contrast in the composition of the two communities was further reinforced by comparing the ten most important species for community structure (IV) in each community, with only Anacardium occidentale occurring on both lists (Table 2).

Figure 3 - Principal Coordinates Analysis of the composition and abundance of woody species studied in two savanna communities on rocky outcrops in the state of Mato Grosso, Brazil

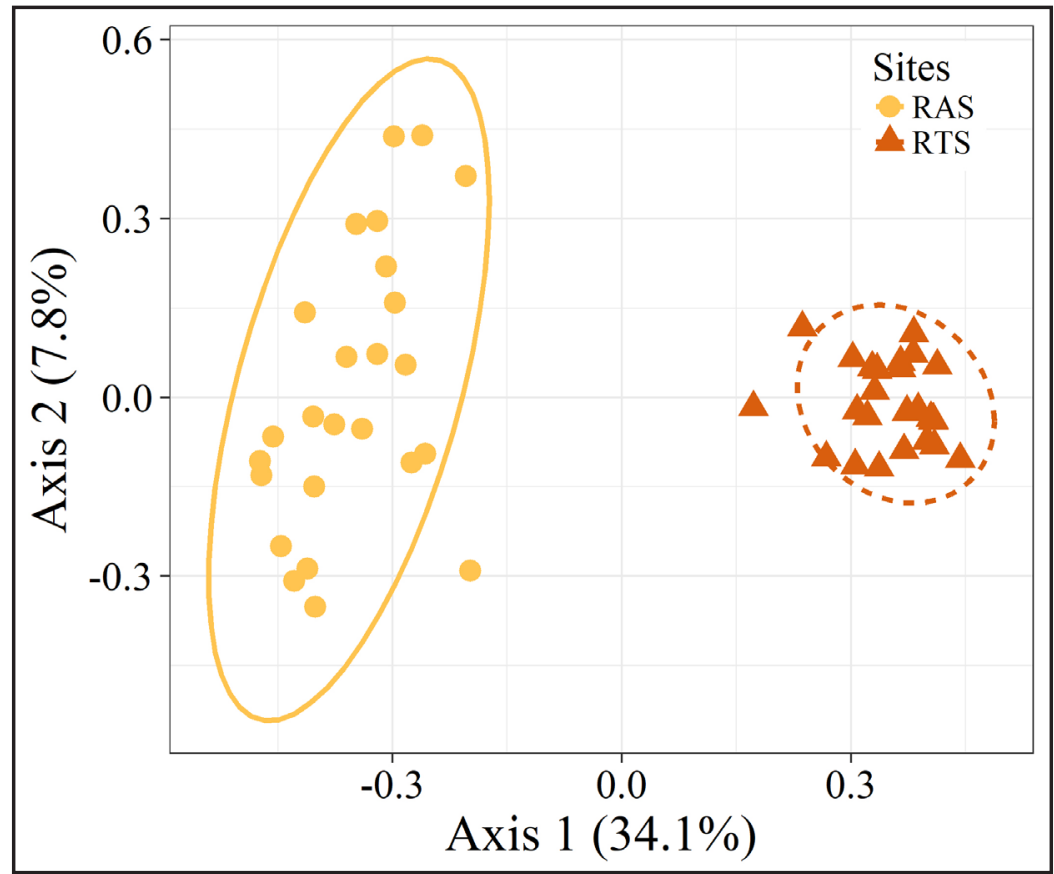

Source: Authors (2021)

In where: RTS = rocky transition savanna in Ribeirão Cascalheira; RAS = rocky amazonian savanna in Nova Canaã do Norte.

Similarity in species composition of the two communities was also low, both qualitatively (Sørensen's index - CS $=0.26$ ) and quantitatively (Morisita's index - $\mathrm{I}_{\mathrm{M}}$ 
$=0.05)$. The similarity between RAS and the two other rocky savanna formations adjacent to the Cerrado-Amazon transition was consistently lower than that found between these formations and RTS (Table 3). The Indicator Species Analysis identified 22 indicator species ( $34.4 \%$ of total) for RTS and 13 indicator species (37.1\% of total) for RAS (Monte Carlo: $p<0.001$; Table 2). The other two rocky savanna communities located in the vicinity of the Cerrado-Amazon transition zone (Table 1: GOMES et al., 2011; ABREU et al., 2012) had greater species richness and were more diverse than RAS, but were quite similar to RTS for both parameters. Considering both Sørensen's index and Morisita's index, the two rocky savanna communities were more similar to RTS than to RAS (Table 3).

Table 3 - Matrix of Sørensen and Morisita similarity indices for compared savanna communities on rocky outcrops in the states of Mato Grosso and Goiás, Brazil

\begin{tabular}{lccccc}
\hline \multicolumn{7}{c}{ Sørensen's index (CS) } \\
\hline & \multicolumn{7}{c}{ RTS * } & RAS* & RNS * & RPS ^ \\
\cline { 2 - 6 } & RTS * & 1 & 0.26 & 0.49 & 0.35 \\
Morisita's index $\left(\mathrm{I}_{\mathrm{M}}\right)$ & RAS * & 0.05 & 1 & 0.15 & 0.12 \\
& RNS * & 0.52 & 0.15 & 1 & 0.60 \\
& RPS & 0.45 & 0.15 & 0.57 & 1 \\
\hline
\end{tabular}

Source: Authors (2021

In where: RTS = rocky transition savanna in Ribeirão Cascalheira; RAS = rocky amazonian savanna in Nova Canaã do Norte; RNS = rocky savanna in Nova Xavantina; RPS = rocky savanna in Piranhas; * Present study; \# Gomes et al. (2011); ^ Abreu et al. (2012).

Soils of the two communities were identified as Litholic Neosols that are poorly drained, dystrophic, alic, extremely acidic and sandy, and with low nutrient concentrations (Table 4). 
Table 4 - Physical-chemical properties of the soil of the studied savanna communities on rocky outcrops in the state of Mato Grosso, Brazil

\begin{tabular}{|c|c|c|c|c|c|c|c|}
\hline \multirow{2}{*}{ Variables } & \multirow{2}{*}{ VIF } & \multicolumn{3}{|c|}{ RTS } & \multicolumn{3}{|c|}{ RAS } \\
\hline & & Mean & SD & Median & Mean & SD & Median \\
\hline $\mathrm{K}\left(\mathrm{mg} / \mathrm{dm}^{3}\right)$ & 2.57 & 0.08 & 0.03 & 0.07 & 0.09 & 0.05 & 0.07 \\
\hline $\mathrm{S}\left(\mathrm{mg} / \mathrm{dm}^{3}\right)$ & 3.43 & 2.48 & 1.09 & 2.00 & 4.98 & 2.08 & 5.00 \\
\hline $\mathrm{Cu}\left(\mathrm{mg} / \mathrm{dm}^{3}\right)$ & 1.45 & 0.78 & 0.40 & 0.80 & 0.52 & 0.22 & 0.60 \\
\hline Sat. Al\% & 7.40 & 55.35 & 10.00 & 56.82 & 78.00 & 9.03 & 81.08 \\
\hline Sand\% & 4.98 & 85.60 & 1.68 & 86.00 & 88.48 & 1.12 & 89.00 \\
\hline$P\left(\mathrm{mg} / \mathrm{dm}^{3}\right)$ & 2.40 & 2.44 & 1.56 & 2.10 & 4.17 & 4.76 & 2.70 \\
\hline $\mathrm{Ca}\left(\mathrm{cmol}_{\mathrm{c}} / \mathrm{dm}^{-3}\right)$ & 2.78 & 0.23 & 0.05 & 0.20 & 0.39 & 0.33 & 0.20 \\
\hline $\mathrm{B}\left(\mathrm{mg} / \mathrm{dm}^{3}\right)$ & 1.20 & 0.22 & 0.05 & 0.23 & 0.21 & 0.04 & 0.23 \\
\hline $\mathrm{Fe}\left(\mathrm{mg} / \mathrm{dm}^{3}\right)$ & 3.22 & 110.52 & 44.70 & 105.00 & 22.36 & 11.36 & 18.50 \\
\hline $\mathrm{Zn}\left(\mathrm{mg} / \mathrm{dm}^{3}\right)$ & 3.75 & 0.67 & 0.63 & 0.30 & 1.81 & 2.22 & 0.90 \\
\hline $\mathrm{Na}\left(\mathrm{cmol}_{\mathrm{c}} / \mathrm{dm}^{-3}\right)$ & 1.65 & 13.72 & 1.37 & 14.00 & 15.12 & 1.24 & 15.00 \\
\hline Sat. Base \% & 6.74 & 13.29 & 4.58 & 13.05 & 4.50 & 1.44 & 4.55 \\
\hline Silt \% & 3.17 & 4.44 & 0.50 & 4.00 & 4.56 & 0.71 & 4.00 \\
\hline $\operatorname{Mg}\left(\mathrm{mg} / \mathrm{dm}^{3}\right)$ & $>10$ & 0.13 & 0.05 & 0.10 & 0.19 & 0.14 & 0.10 \\
\hline $\mathrm{Al}\left(\mathrm{cmolc} / \mathrm{dm}^{3}\right)$ & $>10$ & 0.57 & 0.17 & 0.50 & 2.22 & 0.72 & 2.30 \\
\hline $\mathrm{H}+\mathrm{Al}\left(\mathrm{cmolc} / \mathrm{dm}^{3}\right)$ & $>10$ & 3.58 & 1.11 & 3.50 & 15.48 & 7.64 & 13.90 \\
\hline Organic matter (g/dm³) & $>10$ & 1.90 & 0.51 & 1.80 & 7.92 & 4.84 & 6.80 \\
\hline $\operatorname{Mn}\left(\mathrm{mg} / \mathrm{dm}^{3}\right)$ & $>10$ & 1.14 & 1.12 & 0.80 & 7.42 & 7.40 & 4.20 \\
\hline CEC & $>10$ & 4.08 & 1.09 & 3.93 & 16.22 & 8.06 & 14.33 \\
\hline $\mathrm{pH}$ & $>10$ & 3.82 & 0.18 & 3.90 & 2.98 & 0.22 & 3.00 \\
\hline Clay \% & $>10$ & 9.96 & 1.21 & 10.00 & 6.96 & 0.61 & 7.00 \\
\hline
\end{tabular}

Source: Authors (2021)

In where: RTS = rocky transition savanna in Ribeirão Cascalheira; RAS = rocky amazonian savanna in Nova Canaã do Norte; Sat. Al \% = aluminum saturation; Sat. Base = base saturation; $\mathrm{CEC}=$ cation exchange capacity; SD = Standard Deviation; VIF = Variance Inflation Factor.

The first two axes of the RDA explained $66.9 \%$ and $6.1 \%$ variation, respectively, in the species composition and environment (Figure $4 ; F_{(13,36)}=2.47, p=0.001$ ). The first axis indicated associations of floristic composition with both chemical variables (e.g., higher Base Saturation and Iron content in RTS and higher Aluminum Saturation and Sulfur content in RAS) and particle size variables (e.g., sandier soils in RAS). 
Figure 4 - Redundancy Analysis of the composition and abundance of the woody species and soil physical and-chemical properties for the studied savanna communities on rocky outcrops in the state of Mato Grosso, Brazil

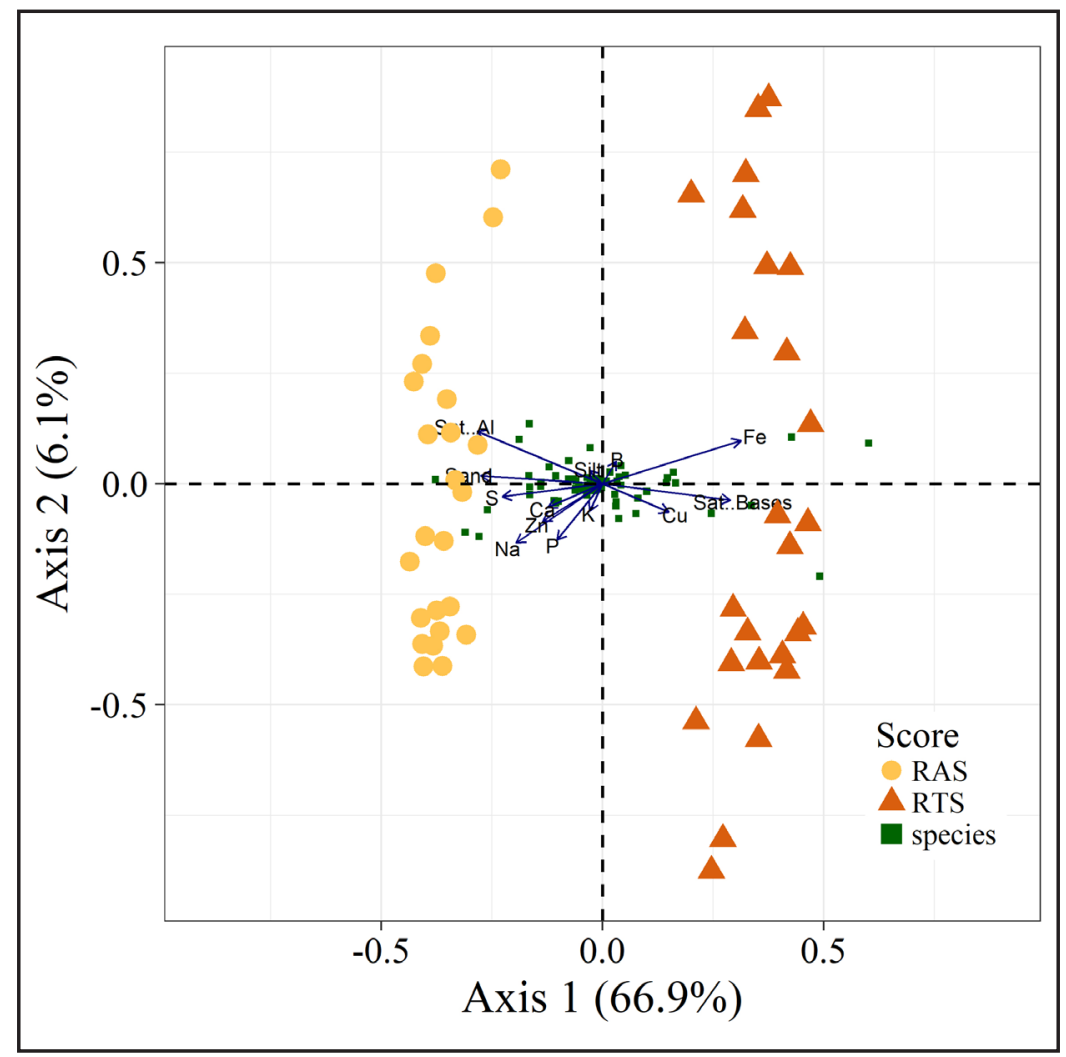

Source: Authors (2021)

In where: RTS = rocky transition savanna in Ribeirão Cascalheira; RAS = rocky amazonian savanna in Nova Canaã do Norte.

\section{DISCUSSIONS}

One important finding of the present study was the low species richness and diversity of RAS ( $n=35)$, which were not only lower than those of RTS ( $n=64)$, but also lower than those of the other Cerrado savanna communities. From 61 to 84 species have been recorded in rocky cerrado communities in the state of Goiás (SANTOS; PINTO; LENZA, 2012), while 71 have been recorded in the state of Mato Grosso (GOMES et al., 2011). All of these values are similar to that recorded for RTS in the 
present study, but higher than the number recorded for RAS. Amazonian savannas typically have lower species richness than savanna formations of the Cerrado (RATTER; BRIDGEWATER; RIBEIRO, 2003; ROCHA; NETO, 2019). It is possible that humidity, geographical isolation, edaphic properties, and in particular, higher concentrations of sand, may be influencing the distinction of the floristic component, once sandy areas usually have fewer species and only two species are predominantly covering more than $50 \%$ of the shrub stratum. Indeed, our RAS results are in accordance with this information due to the higher representativeness of Kielmeyera rubriflora and Parkia cachimboensis, regarding density and importance value (IV) (ROCHA; NETO, 2019).

The limited similarity in species composition between the two studied sites RTS and RAS, in both qualitative (Sørensen=0.26) and quantitative terms (Morisita =0.05), is among the lowest recorded between woody communities in the Cerrado savanna. Values of Sørensen's index for comparisons of rocky cerrado savannas in Brazil ranged from 0.25 to 0.42 (PINTO; LENZA; PINTO, 2009). Comparing ten rocky savanna communities in the state of Goiás, Santos, Pinto and Lenza (2012) recorded values for this index ranging from 0.18 to 0.71 , while scores for Czekanowski's quantitative index ranged from 0.06 to 0.50 . Gomes et al. (2011) reported high values for both Sørensen's (0.75) and Morisita's (0.73) indices in a comparative study of typical and rocky cerrado in Mato Grosso. The comparisons made with two other sites, representing rocky cerrado in the proximity of the Amazon-Cerrado transition zone (GOMES et al., 2011; ABREU et al., 2012) also revealed much greater similarity with RTS than with RAS. These results combined with the high number of indicator species for each community (about a third of the species are indicators for one or the other of the two communities) suggest that RAS is quite distinct from the rocky savannas in both the transition zone and on the Central Brazilian Plateau.

The present study also documented a clear difference in species composition between Amazonian savannas and cerrado sensu stricto. This finding is consistent with what has been reported for communities of these vegetation types located on 
deep soils with no rocky substrate (RATTER; BRIDGEWATER; RIBEIRO, 2003), although the present study is the first to systematically compare communities associated with rocky outcrops. On a broader scale, Amazonian savannas appear to be more similar to each another than to Cerrado savanna formations (RATTER; BRIDGEWATER; RIBEIRO, 2003). Amazonian savannas located in the southern Amazon Basin - Humaitá and Alter do Chão - have a greater affinity, in terms of species composition, for Cerrado savannas of central Brazil than for savannas in the northern Amazonian Basin in the states of Amapá and Roraima (RATTER; BRIDGEWATER; RIBEIRO, 2003). The unique characteristic of Amazonian savannas, rocky or otherwise, appear to be more accentuated in communities located in the central portion of the basin (i.e., RAS), and much less evident in savannas located within or adjacent to the Amazon-Cerrado transition zone (i.e., RTS).

Other studies of savannas on rocky outcrops (referred to as rupestrian fields by many authors) reported that closer areas have greater floristic similarity than more distant areas with the same lithology, and attributed this difference to edaphoclimatic factors, geographic distance and the number of microhabitats existing in outcrops (MESSIAS et al., 2012). Thus, geographical distance seems to promote floristic dissimilarity between savannas located in the interior of the Amazon and those near or in the transition between the Cerrado and the Amazon. In addition, the low similarity between the rocky transition savanna (RTS) and rocky amazonian savanna (RAS) indicates high beta diversity conditioned by the occurrence of environmental heterogeneity due to chemical and physical variation in the soil (MESSIAS et al., 2012).

Despite the similarities between the two study areas in terms of their elevation and underlying substrate, the marked distinctions in their species composition support the classification of RAS as an amazonian savanna due to the presence of woody species typical of both biomes, Cerrado (e.g., Kielmeyera rubriflora) and Amazon, such as Parkia cachimboensis, Alchornea discolor, Pagamea cf. Thyrsiflora and Dacryodes microcarpa, which were present at high densities and structurally important (high IV 
values) in RAS. These four species were not recorded by Santos, Pinto and Lenza (2012) in a broader study on ten rocky cerrado communities, nor at any location studied in Mato Grosso (GOMES et al., 2011; ABADIA et al., 2018). Parkia cachimboensis is found in isolated enclaves of savanna in the Brazilian Amazon Basin, and is thus considered typical of savanna enclaves (ZAPPI et al., 2011), as confirmed in the present study. Norantea guianensis is considered a specialist species that is found exclusively in rocky cerrado of central Brazil (ABADIA et al., 2018). The occurrence of this species in the rocky Amazonian savanna of the present study expands its known distribution to include the interior of the Amazon and confirms its occurrence in rocky habitats in the Amazon.

The evident floristic distinction between RTS and RAS was also determined by soil properties, since the first axis of the Redundancy Analysis, using only local edaphic variables, explained about two thirds of the floristic variation between the two communities. This first axis indicated associations of floristic composition with both chemical (e.g., Base Saturation and Iron in RTS - Aluminum Saturation and Sulfur in RAS) and particle size (e.g., Sand in RAS) variables. In communities from cerrado sensu stricto, the physical and chemical properties of the soil may contribute to distinctions in species composition between different sites, even when they are located within the same local area (ABREU et al., 2012; ABADIA et al., 2018). Thus, it can be concluded that the differences in species composition found here between the two study sites can also be explained, in part, by local edaphic conditions.

\section{CONCLUSIONS}

The present study revealed an evident floristic distinction between the two studied communities, reflected in low values of similarity and high numbers of indicator species for each community. Species richness and diversity were shown to be low in the enclave of rocky amazonian savanna (RAS) compared to the rocky transition savanna (RTS). From the floristic point of view, the cerrado enclave in the 
Amazon has species in common to both the Cerrado and the Amazon. The few species shared between the areas, and typical of the Cerrado biome in RAS (e.g., Kielmeyera rubriflora), can be considered historical remnants of vegetation that were widely distributed in the past when climatic conditions were drier and more favorable to the cerrado vegetation. This study demonstrated that the soils of the two communities lack nutrients, and that soil characteristics are associated with floristic differences. This study also suggests the effect of distance and geographic isolation, as well as the influence of the adjacent flora in the landscape on the richness and composition of species in natural fragments of rocky savannas located in the Amazon, in Cerrado and in the transition zone between them. However, we suggest conducting new studies including other environmental parameters and with a larger number of sites, particularly in the scattered rocky savannas in the Amazon, where there are still few studies. Thus, the environmental, spatial, and floristic effects suggested in the present study, can be evaluated on a larger geographical scale. Such efforts would increase the knowledge about the savanna flora of the Amazon, the transition inselbergs, and the factors that determine the occurrence of savanna formations on rocky outcrops in this ecologically complex region between the Cerrado and Amazon biomes.

\section{ACKNOWLEDGMENTS}

This work was financeb by Coordenação de pessoal de Nível Superior - Brazil (CAPES) - Finance Code 001. We are grateful to Graduate Program in Amazon Biodiversity and Agrosystems, State University of Mato Grosso (UNEMAT), to Paraná State Energy Company (COPEL) for authorizing this work in a permanent preservation area in the contiguity of Colider Hydroelectric Power Plant located in the municipalities of Nova Canãa do Norte and Colider, MT; to Herbarium of the Southern Amazon (HERBAM), to UNEMAT, Alta Floresta Campus, MT, to Herbarium of Nova Xavantina, UNEMAT, Nova Xavantina Campus, MT (NX); to Josias Oliveira dos Santos for helping with statistical tests and data interpretation, Mônica Forsthofer for helping us in the field and all the colleagues who contributed to this study through their valuable criticisms and suggestions. 


\section{REFERENCES}

ABADIA, A. C. et al. Savannas on two different substrates in Brazil have a similar species diversity, but distinct edaphic conditions and species composition. Brazilian Journal of Botany, São Paulo, v. 41, n. 1, p. 57-64, maio 2018.

ABREU, M. A. et al. Influence of edaphic variables on the floristic composition and structure of the tree-shrub vegetation in typical and rocky outcrop cerrado areas in Serra Negra, Goiás State, Brazil. Brazilian Journal of Botany, São Paulo, v. 35, n. 3, p. 259-272, 2012.

ALVARES, C. A. et al. Köppen's climate classification map for Brazil. Meteorologische Zeitschrift, Berlin, v. 22, n. 6, p. 711-728, dez. 2013.

ANGIOSPERM PHYLOGENY GROUP. Angiosperm Phylogeny Group. An update of the Angiosperm Phylogeny Group classification for the orders and families of flowering plants: APG IV. Botanical Journal of the Linnean Society, London, v. 181, n. 1, p. 1-20, 2016.

BERNASCONI, P. et al. Avaliação ambiental integrada: Território Portal da Amazônia. 1. ed. Alta Floresta: Instituto Centro de Vida, 2009. 108 p.

BROWER, J. E.; ZAR, J. H. Field and laboratory methods for general ecology. 2nd ed. Dubuque: Wm. C. Brown Publishers, 1984. 226 p.

CLARKE, K. R.; WARWICK, R. M. Similarity-based testing for community pattern: the two-way layout with no replication. Marine Biology, Berlin, v. 118, n. 1 p. 167-176, 1994.

DUFRÊNE, M.; LEGENDRE, P. Species assemblages and indicator species: the need for a flexible asymmetrical approach. Ecological Monographs, Hoboken, v. 67, n. 3, p. 345-366, 1997.

GOMES, L. et al. Comparações florísticas e estruturais entre duas comunidades lenhosas de cerrado típico e cerrado rupestre, Mato Grosso, Brasil. Acta Botanica Brasilica, Feira de Santana, v. 25, n. 4, p. 866-876, out./dez. 2011.

GOTELLI, N. J.; COLWELL, R. K. Quantifying biodiversity procedures and pitfalls in the measurement and comparison of species richness. Ecology Letters, Oxford, v. 4, n. 4, p. 379391, 2001.

JARDIM BOTÂNICO DO RIO DE JANEIRO. Flora do Brasil: Lista de espécies da flora do Brasil. Rio de Janeiro, 2019. Disponível em: http://floradobrasil.jbrj.gov.br. Acesso em: 08 fev. 2019.

LEGENDRE, P.; BORCARD, D.; ROBERST, D. W. Variation partitioning involving orthogonal spatial eigenfunction submodels. Ecology, [s. I.], v. 93, n. 5, p. 1234-1240, 2012.

LEGENDRE, P.; LEGENDRE, L. Numerical ecology. 3rd ed. Oxford: Elsevier, 2012. 1006 p.

MAGURRAN, A. E. Medindo a diversidade biológica. Curitiba: Editora Universidade Federal do Paraná, 2011. 261 p.

MCCUNE, B.; MEFFORD, M. J. PC-ORD. Multivariate Analysis of Ecological Data. Version 6.07. Gleneden Beach: MjM Software, 2011. 
MESSIAS, M. C. T. B. et al. Fitossociologia de campos rupestres quartzíticos e ferruginosos no Quadrilátero Ferrífero, Minas Gerais. Acta Botanica Brasilica, Porto Alegre, v. 26, n. 1, p. 2302142, 2012.

MORO, F. M.; MARTINS, F. R. Métodos de levantamento do componente arbóreo-arbustivo. In: FELFILI, J. M. et al. (ed.). Fitossociologia no Brasil: métodos e estudos de casos. Viçosa, MG: UFV, 2011. p. 556.

MUELLER-DOMBOIS, D.; ELLENBERG, H. Aims and methods of vegetation ecology. New York: John Wiley and Sons, 1974. 547 p.

NAIMI, B. et al. Where is positional uncertainty a problem for species distribution modelling. Ecography, Copenhagen, v. 37, n. 2, p. 191-203, 2014.

OKSANEN, J. et al. Vegan: Community Ecology Package. R package version 2.5-1. [S. I.: s. n.], 2018. Available from: https://CRAN.R-project.org/package=vegan. Access: 03 mar. 2021.

PINTO, J. R. R.; LENZA, E.; PINTO, A. S. Composição florística e estrutura da vegetação arbustivoarbórea em um cerrado rupestre, Cocalzinho de Goiás, Goiás. Revista Brasileira de Botânica, São Paulo, v. 32, n. 1, p. 23-32, jan./mar. 2009.

POREMBSKI, S.; SILVEIRA, F. A. O.; FIEDLER, P. L. Worldwide destruction of inselbergs and related rock outcrops threatens a unique ecosystem. Biodiversity and Conservation, London, v. 25, p. 2827-2830, set. 2016.

R CORE TEAM. R: a language and environment for statistical computing. Version 3.1.0. Vienna: R Foundation for Statistical Computing, 2018. Available from: https://www.R-project.org/. Access: 03 mar. 2021.

RATTER, J. A.; BRIDGEWATER, S.; RIBEIRO, J. F. Analysis of the floristic composition of the Brazilian cerrado vegetation III: comparison of the woody vegetation of 376 areas. Endinburgh Journal of Botany, [s. I.], v. 60, n. 1, p. 57-109, mar. 2003.

ROCHA, A. E. S.; NETO, S. V. C. Florística e fitossociologia do estrato herbáceo/arbustivo em 19 áreas de savanas amazônicas, Brasil. Boletim do Museu Paraense Emílio Goeldi, Belém, v. 14, n. 1, p. 159-181, 2019.

SANTOS, H. G. et al. Sistema brasileiro de classificação de solos. 5. ed. Brasília, DF: Embrapa, 2018. 356 p.

SANTOS, T. R. R.; PINTO, J. R. R.; LENZA, E. Floristic relationships of the woody component in rocky outcrops savanna areas in Central Brazil. Flora, [s. I.], v. 207, n. 7, p. 541-550, jul. 2012.

SHEPHERD, J. FITOPAC 2.1. Campinas: Departamento de Biologia Vegetal, Universidade Estadual de Campinas, 2009.

TÓTHMÉRÉSZ, B. Comparison of different methods for diversity ordering. Journal of Vegetation Science, Knivsta, v. 6, n. 2, p. 283-290, 1995.

ZAPPI, D. C. et al. Plantas vasculares da região do Parque Estadual Cristalino, Norte de Mato Grosso, Brasil. Acta Amazonica, Manaus, v. 41, n. 1, p. 29-38, mar. 2011. 


\section{Authorship Contribution}

\section{1 - Marcos José Gomes Pessoa}

Biologist, MSc., Doctoral Candidate

https://orcid.org/0000-0001-7424-2449•marcos-af@hotmail.com

Contribution: Conceptualization, Formal Analysis, Investigation, Methodology, Validation, Visualization, Writing - original draft, Writing - review \& editing

\section{2 - Leonardo Maracahipes-Santos}

Biologist, Dr., Researcher

https://orcid.org/0000-0002-8402-1399•maracahipesbio@gmail.com

Contribution: Conceptualization, Formal Analysis, Investigation, Methodology, Validation, Visualization, Writing - original draft, Writing - review \& editing

\section{3 - Ana Clara Abadia}

Biologist, Dr.

https://orcid.org/0000-0002-2773-8588•claraabadia@hotmail.com

Contribution: Conceptualization, Formal Analysis, Investigation, Methodology, Validation, Visualization, Writing - original draft, Writing - review \& editing

\section{4 - Bianca de Oliveira}

Biologist, MSc.

https://orcid.org/0000-0001-8792-0122•biancadeoliveira89@gmail.com

Contribution: Investigation, Methodology, Writing - original draft

\section{5 - Ivone Vieira da Silva}

Biologist, Dr., Professor

https://orcid.org/0000-0003-0281-0608•ivibot@hotmail.com

Contribution: Conceptualization, Investigation, Methodology, Writing - original draft

\section{6 - Eddie Lenza}

Biologist, Dr., Professor

https://orcid.org/0000-0001-9139-5949•eddielenza@yahoo.com.br

Contribution: Conceptualization, Formal Analysis, Funding acquisition, Investigation, Methodology, Project administration, Resources, Supervision, Validation, Visualization, Writing - original draft, Writing - review \& editing 


\section{How to quote this article}

Pessoa, M. J. G.; Maracahipes-Santos, L.; Abadia, A. C.; Oliveira, B.; Silva, I. V.; Lenza, E. Floristic composition, diversity and edaphic effects in two rocky savanna communities in the Amazon and Cerrado, Brazil. Ciência Florestal, Santa Maria, v. 31, n. 3, p. 1383-1406, 2021. DOI 10.5902/1980509841937. Available from: https://doi.org/10.5902/1980509841937. Accessed: xx abbreviated-month. 2021. 